THE TYNDALE NEW TESTAMENT LECTURE, 1975*

\title{
THEOLOGICAL DIVERSITY IN THE LETTERS OF ST. PAUL
}

\section{By JOHN W. DRANE}

In my recent book, Paul: Libertine or Legalist?,' ${ }^{1}$ I have put forward the thesis that on the important themes of the significance of tradition and revelation for Christian belief, and the place of law in the Christian life and ethic, significant variations can be traced in the teaching of the four major Pauline letters, Galatians, 1 Corinthians, 2 Corinthians (plus or minus chs. 10-13), and Romans. Leading from this observation, I have argued that we can utilise such diversity of theological expression as a valid test to determine not only the direction of Paul's own thinking but also the nature of the opponents with whom he was dealing during this period of his ministry. Indeed, the nature of these variations is such that we can characterise 1 Corinthians in particular as a kind of proleptic 'early catholic' document, used by Paul to deal with his Gnostic opponents in Corinth in much the same way as the later Fathers used similar arguments to oppose the Gnostic threat in the second century. A basic premise of this argument is that 1 Corinthians is dependent on Galatians in such a way that the latter epistle must undoubtedly be dated earlier than any part of the Corinthian correspondence.

Such a view of Pauline theology, not to mention its implications for the relative chronology of the letters, is of course far from being widely accepted, and even on other, more historical grounds it is not often conceded that Galatians could be of early date. The majority of New Testament scholars are

* Delivered at Tyndale House, Cambridge, on July 9th, 1975.

${ }^{1}$ London, 1975. Cf. also my earlier article, 'Tradition, Law and Ethics in Pauline theology', in NovT 16 (1974) 167-178. 
still convinced by the arguments of J. B. Lightfoot ${ }^{2-}$ and feel that, since Galatians appears to have more in common with Romans and 2 Corinthians than it does with admittedly early letters like 1-2 Thessalonians, it cannot therefore be given an early date, no matter how strong the historical evidence on the other side may be.

In recent years, the historical evidence relative to the origin of the various epistles has been frequently re-examined. ${ }^{3}$ But the internal evidence of the theology of the epistles themselves has not been subjected to the same.kind of enquiry. Rather has it come to be accepted as an unquestionable assumption of Pauline research that Romans and Galatians, being closely related in certain of their most distinctive elements, must stand in a close relationship to each other, both chronologically and logically, in the development of Pauline thought. Very few scholars have bothered to examine this position, and those who have done so have unanimously concluded that such diversity as is traceable in Paul's writings proves beyond doubt that the correct order of the 'capital epistles' was 1 Corinthians, 2 Corinthians (with or without chs. 10-13), Galatians and Romans.

One of the most influential of these scholars has been the American, Charles Buck, and in his magnum opus (with G. Taylor), Saint Paul: a study of the development of his thought, ${ }^{4}$ he argues that a complete and detailed chronology of the development of Pauline thought can be worked out by a comparative study of the epistles. Taking up the same method as Professor John Knox, and disregarding the evidence of Acts, ${ }^{5}$ he claims to be able to show not only that Paul's theology developed, but that it developed in three quite distinct and dateable stages: the early stage, represented by 1-2 Thessalonians; the middle stage, including 1-2 Corinthians, Galatians and Romans; and the late stage which contains Philippians, Colossians, Philemon and Ephesians. He reaches this conclusion mainly on the basis of Paul's changing eschatological outlook, an aspect of Pauline thought that has not been considered in any detail in my previous work on the subject. But since Buck reaches con-

2 J. B. Lightfoot, St. Paul's Epistle to the Galatians, London (1875) 35-55.

${ }^{3}$ On Galatians, see especially the series of five articles on 'Galatian Problems' by F. F. Bruce, in successive volumes of BJRL from 1969 to 1973.

${ }^{4}$ New York (1969).

${ }^{5}$ Cf. J. Knox, Chapters in a Life of Paul, Nashville/New York (1950). 
clusions on this ground which are diametrically opposed to my own previous conclusions, it is clearly important that my own hypothesis should now be subjected to further scrutiny in the light of Buck's arguments on Pauline eschatalogy. It is therefore my intention here to examine some of these arguments, and then to reappraise my own earlier conclusions in the light of them.

Accordingly, we first turn our attention to a statement of the issues involved, after which we move to 1 Corinthians 15 , which is a crux interpretum for any theory that claims to find diversity in Pauline thought. In the light of our understanding of this passage, we shall then examine the evident diversity within Paul's eschatological teaching; and finally we must consider the implications of all this for the controverted questions of diversity in Paul's theology, and the chronological sequence of his main letters.

The starting point for Buck's examination of the Pauline letters is the correspondence with the church at Corinth. This is perhaps not the most promising place to begin any assessment of Pauline thought, in view of the extreme complications that surround these epistles, but Buck starts here because he believes that the references made to the collection for the Jerusalem church (1 Cor. 16:1-11, 2 Cor. 8:1-7, 9:1-5, cf. Rom. 15:24-29) necessitate the view that

1 Corinthians, 2 Corinthians 1-9 and Romans must have been written in that order, and within the space of about eight months. The recognition of this gives him what he supposes to be an objective test of the variations of theological belief in these three letters. Since they can be dated in that order on more or less historical grounds, a simple examination of their doctrines will give an indication of the direction in which Paul's thought was moving.

Unfortunately, it is not possible to preserve this appearance of objectivity for long, for no sooner do we turn to 1 Corinthians than we are faced with the problematical 'Previous Letter'. Following J. C. Hurd, ${ }^{6}$ Buck argues that most of the

6 The Origin of 1 Corinthians, London (1965). Hurd was in fact a student of Buck's, and in his own book acknowledges his prior debt to the latter. 
difficulties in the Corinthian church had arisen as the result of this letter, a letter which was allegedly legalistic and authoritarian in tone, and which the Corinthians rejected, or at least objected to, on the ground that its contents ran quite counter to Paul's first teaching in Corinth, and also to his own known conduct as a Christian. There had clearly been a change in the situation at Corinth between the time of Paul's first visit there and the writing of the Previous Letter, a change that was facilitated by the volatile nature of many of the church members themselves, and was indeed implicitly encouraged by the fact that Paul, for his part, had not prepared them very well for coping as Christians with the everyday events of real life in a pagan context. ${ }^{7}$

According to Buck, the reason for this inadequacy in Paul's teaching is to be found in the assumption that at the time of his first visit to Corinth Paul believed that the parousia of Jesus was imminent, and so any ethical teaching concerned with life in this world was quite irrelevant. But it was not long before both Paul and his converts had to face up to reality, the reality being that they were all growing older, and some had actually died. Paul therefore found it necessary to explain in greater detail his precise thinking on the fate of Christians who died before the parousia, and this, in Buck's view, forms the central theme of the core of 1 Corinthians, which he locates in ch. $15 .^{8}$

Working on this somewhat dubious assumption, Buck goes on to compare 1 Corinthians 15 with the similar section of 1 Thessalonians (4:13-18), where the same subject is dealt with. There Paul mentions a special resurrection of Christians over against the general resurrection of the dead, something he had apparently not previously spoken of in Corinth. 1 Corinthians 15 now becomes Paul's effort to remedy this deficiency, though in this context he goes a stage further and asserts that not only the dead but the living also will be affected, changed into new bodies of Spirit at the same time as those who are resurrected (1 Cor. 15:51-55).

Arguments such as this enable Buck to assign a place to 1 Thessalonians in the development of Paul's thought. On his

${ }^{7}$ According to Buck, St. Paul 37f, Paul himself recognises this inadequacy with his statement in 1 Cor. 3:1-2, that 'I fed you with milk, not solid food '..' ${ }^{8}$ On all this, cf. Buck, St. Paul 31-45. 
understanding of the matter, both 1 Thessalonians and the Previous Letter to Corinth deal with the same question in precisely the same way: i.e. the effort to modify an originally apocalyptic and imminent expectation to take account of the fact that some Christians had already (and unexpectedly) died. Since 1 Corinthians 15 is taken as a further expansion of Paul's teaching on the same subject, 1 Thessalonians must be dated earlier than this, and it can therefore only be fitted in, logically and chronologically, between Paul's first visit to Corinth and his writing of 1 Corinthians, at about the same time as the Previous Letter. ${ }^{9}$

Thus, Buck argues for the following development in Paul's eschatological thought:

1. The parousia is imminent, and all Christians will live to see it (Paul's original conviction).

2. The Christian dead will be raised at the parousia (1 Thessalonians and the Previous Letter).

3. The dead will be raised with bodies of Spirit, and the living will also be changed to bodies of Spirit (1 Corinthians 15).

Yet as he moves on to examine 2 Corinthians 1-9, it becomes clear that a fourth step must follow: ${ }^{10}$

4. In 1 Corinthians 15 , the change of flesh to Spirit is instantaneous; in 2 Corinthians (3:17f, 5:1-4, 4:16ff) it is gradual, starting at conversion and continuing until final resurrection.

Indeed, the whole question of death undergoes a radical reorientation between 1 Corinthians and 2 Corinthians 1-9.11 In 1 Corinthians $(5: 3,5 ; 11: 27 \mathrm{ff}$, etc. $)$ death is still something quite exceptional and unexpected - a punishment for sin. But in 2 Corinthians (5:1415) death is no longer regarded as judgement: it is rather "the climax of the process by which [the Christian] has been transformed from flesh to spirit", and it is something that has happened already, so that the Christian is even now a new creation. ${ }^{12}$

This "significant modification" of Paul's thought took place in the space of something like seven weeks, and it was brought about by Paul's own brush with death in Asia, which caused him to see the inadequacy of his earlier view (cf. 2 Cor.

9 Buck, St. Paul 46-52.

10 Buck, St. Paul 53ff.

11 St. Paul 55ff.

12 Buck, St. Paul 57. 
$1: 8-10){ }^{13}$ It was a change of direction which cannot be underestimated in importance, for it also led to a radically new direction in Paul's thought on two other important topics: the Law and Christology.

Buck's contention that Paul's attitude to the Torah of the Old Testament in 2 Corinthians 1-9 is radically different from that in all the other letters which he has discussed (1 Thessalonians, the Previous Letter to Corinth and 1 Corinthians) is a gross exaggeration, since the Law is never mentioned at all in 1 Thessalonians, while the content of the Previous Letter to Corinth can only be arrived at by guesswork. Yet he is undoubtedly correct in his observation that there is a real distinction here between what Paul says in 1 Corinthians and his later comments in 2 Corinthians 1-9. 1 Corinthians gives no indication at all that law is irrelevant for the Christian. Quite the reverse is the case, for not only does Paul assert in 1 Corinthians 7:19 that 'keeping the commandments of God is everything', but he also consistently lays down his own rules and regulations to cover many different situations in life. There are rules for everything, from the very real dangers presented to the Christian by involvement in a pagan society, to the perils of angelic exposure to a woman's uncovered head. There is no doubt that the whole tone of 1 Corinthians is intensely legalistic, and on several occasions Paul actually quotes from the Old Testament Torah to support his own positions. Yet in 2 Corinthians 1-9, Paul makes it quite clear that the Law (and including legalism as such) is irrelevant for the Christian, indeed more than irrelevant: it is the dispensation of condemnation and death, and those who continue to observe it are behaving contrary to the will of God (cf. 2 Cor. 3:6-9).

On Buck's interpretation of these facts, the variations in Paul's attitude both to the Torah and to the larger question of law in the Christian life as between 1 Corinthians and 2 Corinthians is to be seen as the natural outcome of his newly developed eschatological idea that the flesh of Christians is gradually being changed to Spirit. Except, in the case of the Law, this doctrine of "the simultaneous possession of two natures" is working in reverse: the spirit has already left the

${ }^{13}$ Buck, St. Paul 58. This view was developed especially by C. E. Faw, 'Death and Resurrection in Paul's letters', in Journal of Bible and Religion 27 (1959) $291 \mathrm{ff}$. 
Law, leaving only the carved letters of stone, and thus its observance can only lead to death. ${ }^{14}$

Buck then proceeds to apply the same test to the Christological doctrines of 2 Corinthians 1-9, and he finds that these too have been altered by the application of Paul's newly devised two-natures doctrine. Whereas in 1 Thessalonians and 1 Corinthians the work of Christ begins with his death, in 2 Corinthians 1-9 the work of Christ now begins before his death, so that Paul can see the presence of divine attributes in Jesus even during his earthly life. And all this is "yet another form of the eschatological doctrine of the simultaneous possession of two natures, for if God was at work in Christ during his earthly life, then at that stage of his existence Christ was not a being of flesh and blood only. He had possessed a heavenly nature as well."15

Buck also considers the significance of the differences between 1 and 2 Corinthians and what preceded them, and the two other major epistles, Galatians and Romans. He believes that the argument of Galatians shows it to come midway between 2 Corinthians 1-9 and Romans, on three main grounds: ${ }^{16}$

1. The Historical Evidence of Galatians 1 and 2, which centres on three main elements: Paul's visit to Jerusalem $(1: 18,21)$, the request of James, Cephas and John that he remember the poor (2:10), and the subsequent controversy with Cephas and the Judaizers in Antioch (2:11 ff). All this suggests that "Paul's response to the request that he should remember the poor was the collection mentioned in the Corinthians correspondence ard Romans, and that the controversy with the Judaizers that began in Antioch was the same as that reflected in Philippians, II Corinthians 1-9, and Romans. The alternative supposition, that these letters reflect a different effort on behalf of the poor of Jerusalem which coincided in time with a different controversy over the keeping of the law, seems not convincing. The letters give the impression that there was only one collection and only one controversy with the Judaizers." 17

This is a very weak argument. In the first place, it rests on

14 Buck, St. Paul 60-64.

15 Ibid, 66.

16 On all this, cf. Buck, St. Paul 82-102.

${ }^{17}$ Ibid, 83. 
the assumption that the whole period of Paul's ministry corresponded exactly with the period of composition of the extant letters. But since on any account the events described in the first two chapters of Galatians took place over a considerable period of time, and since even Buck's theory is unable to provide any definitive, as opposed to relative chronology of Paul's ministry, it seems wholly possible that some of the events referred to there took place long before any of the letters were written, and are therefore of no direct relevance to our consideration of their internal development. In addition, Buck seems to imagine that Paul could be expected to mention every incident of his ministry somewhere in one of his letters. But this assumption is no more justifiable than is the older assumption that Acts contains a full record of Paul's life and ministry. The letters were never intended to be a chronicle of Paul's life, and much stronger evidence than this is required to support the statement that the dispute and collection of Galatians 1-2 are identical with the disputes and collection of 2 Corinthians 1-9.

Buck claims, of course, that there is other evidence to prove just this point, namely

2. The 'literary' evidence. The argument at this point consists of a restatement of the theory of J. B. Lightfoot, who argued that Galatians was the model for the composition of Romans, and that 2 Corinthians was earlier than Galatians. The evidence for this is said to be found in the varying use of the Pauline antitheses of spirit/flesh and faith/works, as they are found in 1 Corinthians, 2 Corinthians 1-9, Galatians and Romans. The antithesis of spirit/flesh is found in all four epistles, but that of faith/works is found in its most characteristic Pauline usage only in Galatians and Romans. Moreover, in Galatians Paul unites the two pairs spirit/flesh and faith/ works, and in Buck's view "We may now ask whether it is likely that Paul, having once made this identification between the two pairs, and having used them in such intimate connection, should have failed to make the same identification, and ignored this connection, in a later discussion of the identical problem.".18

Again, this evidence is less than convincing. While it may seem to Buck that Paul ought not to take up a theme in one letter and then drop it in another, only to re-adopt it later ${ }^{18} \mathrm{Ibid}, 90$. 
on, this is a purely subjective judgement. No doubt the modern scholar would not change his arguments so often or so easily, but thatsis hardly a good enough reason to suppose that Paul, writing as a pastor to people in desperate need of his advice, would spend time carefully reading what he had written in another letter to ensure there was no possibility of appearing to contradict himself.

3. The Theological Evidence. Nor are we given any greater confidence in the evidence drawn by Buck from the actual content of Galatians and Romans. To be sure, he argues that the eschatology of the two epistles can be seen as a logical continuation of the semi-realised eschatology of 2 Corinthians $1-9$, in which the statement of 2 Corinthians $5: 14$, that 'because one has died for all ... therefore all have died', is taken up and expanded in Galatians 2:20 and Romans 6:4 into a thoroughgoing doctrine of Christ mysticism in which both death and resurrection have already taken place in the life of the believer. But the connexion between these three passages does not of itself necessitate the assumption that any line of development can be traced from one to the other. That is only obvious if Buck's theory is taken as a basic presupposition. Otherwise, the occurrence of the same theme in the three contexts suggests nothing more profound than the observation that it must have been an important element of Pauline theology.

On Paul's attitude to the Law in these three letters Buck's argument is in general much more illuminating. He observes quite rightly that the legal theory of Galatians is altogether different from that of 2 Corinthians 1-9. In 2 Corinthians 1-9 Paul argues simply that the old covenant has been replaced by the new (2 Cor; $3: 6,14)$ and that the Old Testament Torah is irrelevant for the Christian because it applied only for a limited time (2 Cor. 3:4-18). Galatians, on the other hand, presents "a far more radical and extreme position", a position in which it is clearly stated that the Law was not the gift of God himself, but of the angels (3:19), and moreover that it had a severely limited jurisdiction: "There was a time before its enactment when it was of no effect, and there is a time after its expiration when it is of no effect. The promise was made in the former of these times; the fulfilment of the promise has come about in the latter." 19

19 Ibid, 99. 
The statements about the Law in Galatians were clearly extreme statements made by Paul to meet an extreme situation, and if carried to their logical conclusion could only have led to some kind of Gnostic belief denying both the sovereignty of God and the inspired nature of the Old Testament. ${ }^{20} \mathrm{We}$ are therefore not surprised to find that Galatians was by no means Paul's final word on the relevance of the Old Testament for the Christian. In Romans he takes up the same questions again, this time in a less controversial context, and though he takes something like the Galatians arguments as the basis of his thought, he carefully modifies them so as to exclude any possibility of misunderstanding.

Romans has no mention of angels or stoicheia in connexion with the Law. Whereas in Galatians men under the Law are described as slaves of the stoicheia $(4: 3,9)$, in Romans they are slaves of $\sin (6: 16 \mathrm{ff})$. Paul goes out of his way here to emphasise that what he attacks is not God's law $(3: 31,7: 12$, 22 , etc. ), but rather another law, the 'law of sin' (7:23), which though it is a reflexion of God's law is the instrument of a different sovereign. 'The law of the spirit of life' can release men from this law of sin and death (8:2), and it does so through the work of Christ understood in a context of realised eschatology: since the Christian's 'body of flesh' is dead already, he is now dead with Christ, and is therefore dead to sin, whose only domain can be over the flesh (Rom. 6:6-11). Conversely, having received the Spirit, the Christian must always be alive to God.

Thus Buck argues, correctly in my opinion, that Romans can be seen as a combination of elements of Galatians and 2 Corinthians 1-9. Though I should want to add that 1 Corinthians acted as the catalyst in this fusion, the overall picture can stand independently of whatever view we may take of the relative place of these three epistles in the life and experience of St. Paul.

\section{II}

We leave Buck's argument at this point, and turn to ask some of the fundamental questions which seem to arise from this kind of approach to the Pauline literature:

${ }^{20}$ On the angels and the law in Galatians, cf. my Paul: Libertine or Legalist?, 32ff, $112 \mathrm{f}$. 
a. Is there any evidence to suggest that the theology of the epistles is at points inconsistent with itself?

$b$. If there are inconsistencies, do they amount to any kind of development in Paul's thought?

c. Is Buck's reconstruction of this development correct, or should the evidence be interpreted in some other way?

The first of these questions has already been answered, for we have seen that in his statements on the Law Paul does not say precisely the same things in every context where he mentions the subject. What is more, alongside the diversity of Paul's teaching on the Law and its relevance for the Christian, we also find a corresponding variation in his ethical advice and his emphasis on the importance of tradition for conventional Christian belief. ${ }^{21}$ It is clear that if we are dealing with a total body of thought that we call 'Pauline theology', there is no real difficulty in seeing how the various strands of Paul's teaching can hang together - and in that context it becomes clear that the diversity of expression traceable in the individual letters is directly related to the diversity of the opponents against whom Paul was writing. Indeed, the variations of his theological expression can be utilised as an indispensable clue to identify the character of such opponents in different situations. To this extent we could say that the expression of Paul's theology was moulded by the events of his own life and ministry. But that is not saying much more than that Paul was a wise strategist, who expressed himself in terms that were relevant to whatever situations he found himself in, and who was willing to learn from his mistakes. This kind of theological diversity certainly does not presuppose any formal system of development in Paul's thinking, and in this respect the hypothesis I have suggested is altogether different from that put forward explicitly by Buck, and accepted implicitly by a large number of other New Testament scholars.

But what of Paul's eschatological outlook? If this really did change, whether in the precise way postulated by Buck, or in any of the other ways that have been suggested from time to time, ${ }^{22}$ this would necessitate a complete reappraisal of the other evidence to which I have previously drawn attention. We may even need to conclude that the variations of approach to the Law, Christian ethics and the place of revela-

21 Paul: Libertine or Legalist? 60-77.

22 E.g. C. H. Dodd, New Testament Studies, Manchester (1953) 67-128. 
tion in Christian belief as between Galatians, 1 and 2

Corinthians and Romans are nothing more than random variations in Paul's language, unrelated in any systematic way either to the opponents whom the apostle was facing or to any alleged development in his own thinking.

We must therefore ask whether Buck's interpretation of the evidence of the epistles is in fact correct, or whether the evidence can and should be taken in some other way.

Several general criticisms can be made of the attempt to understand the variation of Paul's theological expression by means of such a theory of formal development in Pauline thought.

A major weakness in this theory (and that of Hurd et al.) stems from the fact that the central evidence on which the whole hypothesis is constructed is of an indirect nature. At every crucial point in the exposition of Paul's thought Buck's argument is based on an inference. The reconstruction of the Previous Letter to Corinth is central to the theory, yet there is no objective basis available to anyone for ascertaining the precise contents of this letter. Buck's view of it as a legalistic, authoritarian document is, and can always be, based on nothing more than intelligent guesswork. Nor is there any firmer foundation for the belief that Paul originally thought all Christians would live until the parousia, or that the apostle once thought it was wrong for Christians to marry. For all of this there is no direct and conclusive evidence of any sort.

In addition, Buck seems to assume that Paul can be expected to write all that he believes in every epistle, and that if something is not stated that means he did not believe it at the time of writing. We have noticed, for example, the contrast between Paul's treatment of the Law as between 1 Corinthians and 2 Corinthians, a distinction which could be explained in several ways. The theory that Paul's thought was undergoing some form of radical development is one possible explanation, but there are others. Buck always chooses the development theory as the correct one. On this specific point, for example, he comments: "It is thus absolutely clear that when he wrote I Corinthians, Paul had not yet taken the position of II Corinthians 1-9 .."23 But this is not a conclusion that necessarily follows from the mere observation that there are differences between the two epistles. Indeed, if we consider these

${ }^{23}$ St. Paul 63. 
letters in their historical situation, and interpret them in the light of the opponents whom Paul was dealing with in each instance, there is no problem at all in reconciling (if that is the right word) the different nuances of his thought. For in 1 Corinthians he seems to be arguing against some kind of libertine Gnostics, to whom the appropriate response was an emphasis on the importance of law and order in the Christian life, while in 2 Corinthians 1-9 his opponents appear to be Jews or Judaizers, to whom the appropriate response was a devaluation of the Old Testament Law. Similarly, Buck's neat categorisation of the alleged distinctions in Paul's understanding of the antitheses of spirit/ flesh and works/law in Galatians, 1 and 2 Corinthians and Romans could never have been made so simplistically had adequate consideration been given to the background of the various letters, and especially to the question of Paul's opponents in Galatia and Corinth.

One of the most disturbing things about this whole theory is that it seems to have been constructed quite independently of any appreciation of the real situations in which Paul found himself. If we visualize Paul under the guise of a twentieth century academic writing monographs on theology, then the variations in his expression may well be thought to represent some kind of development in his thought. But if we see him as a pastor dealing on a more or less $a d$ hoc basis with the problems of Christian living as and when they arose, the picture we get of him is quite different. Would a modern pastor when faced, say, with over-enthusiastic charismatics on the one hand, and British Israelites on the other, give precisely the same advice to each group? I think not. Nor ought we to be so naive as to imagine that Paul would have done so.

Even apart from the general problems noted so far, there are certain inconsistencies within the argument which Buck puts forward, even on his own premises. For instance, a main plank in his argument is the assertion that 1 Thessalonians could not be later than 1 Corinthians since 1 Corinthians 15 has what he takes to be a further expansion of the eschatological teaching of 1 Thessalonians $4-$ and "it is inconceivable that Paul, having discovered the necessity for this expansion, should subsequently have omitted it from 1 Thessalonians." 24 Yet, 'inconceivable' or not, this is the very procedure that Buck supposes Paul to have adopted between ${ }^{24}$ Ibid, 47. 
the writing of 1 Corinthians and the composition of Galatians!

He argues strongly that the detailed moral teaching of 1 Corinthians was formulated by Paul when he saw that his earlier, apocalyptically dominated teaching had been overtaken by events. Now if the realisation that the parousia was not to be immediate was a fundamental turning point in the apostle's thinking, we may well suppose that in every letter written after this discovery he would be at pains to explain the specific ways in which Christians should behave in a continuing society. Yet when we come to Galatians, allegedly written later than 1 Corinthians, we search in vain for any kind of specific ethical teaching, and the overall impression left by Galatians is that good behaviour is something produced in the Christian by the Holy Spirit, and that rules and regulations, whether moral, religious or otherwise, are quite irrelevant. ${ }^{25}$

Buck does find a place for such a moral theory in his scheme: it is said to represent the very earliest and most primitive form of Pauline thought, reflected in his view in 2 Thessalonians, which is described as follows: "The ethical system of the letter, if indeed it can be called a system, is simplicity itself . . . the assumption of the letter is that the Spirit will guide the believer to behave as becomes a saint. This, of course, is far simpler and more primitive than the ethical outlook even of 1 Thessalonians." 26 Yet this is exactly the kind of ethical system presented in Galatians, and it is hard to understand how such an obvious comparison can be ignored. Whatever else Paul may have learned from the church at Corinth, the central part of his discovery was that the principles of law and order were not so irrelevant to Christian experience as his teaching on justification by faith alone had led some of his converts to suppose. In view of this, we would need very strong evidence before we could believe that, once having learned the lessons of Corinth, Paul would have reverted to the kind of vague moral exhortation that we find in Galatians.

\section{III}

The contrast between 1 Corinthians and Galatians here directs

${ }^{25}$ Cf. Paul: Libertine or Legalist? $55 \mathrm{ff}$.

26 St. Paul 144. 
our attention to the main point at issue in the discussion of theological diversity in Paul's epistles. For the heart of Buck's theory about the development of Paul's thought is found in his interpretation of 1 Corinthians 15 , from which he draws the following conclusions: ${ }^{27}$

$i$ Paul's initial teaching to the Corinthian Christians had been based on the belief that the parousia was to be immediate, and Christians would never die.

ii Subsequent to that, Paul had modified his teaching in the Thessalonian church, to accommodate the fact that Christians had died. The Corinthians heard of his new emphasis on a general resurrection and a special resurrection of Christians, and asked why they had not heard of it before.

iii In reply to the Corinthians' questions, Paul took his own beliefs a stage further, to include the transformation of living Christians at the same time as the resurrection of those who were dead.

Though Buck states all these conclusions with a great show of confidence, it is not always easy to see just how they follow from what Paul actually says here. Though the chapter is not the easiest to understand, at least five points do seem to be fairly clear:

1. It is likely, as Buck himself asserts, that the problems of the Corinthians about the meaning of 'resurrection' had arisen to some considerable extent out of a misunderstanding of Paul's own previous teaching. J. C. Hurd has shown that this section of 1 Corinthians was probably written in answer to questions asked of the apostle, ${ }^{28}$ while verses 1,3 and 11 make it clear that these questions were concerned with the correct understanding of the traditions about the resurrection of Jesus vis-à-vis some other teaching given by Paul himself.

2. It also seems clear that the Corinthians did actually believe that Jesus himself had risen from the dead. This much is implied by Paul's statements about his own original message and its reception in Corinth. ${ }^{29}$

3. Some Corinthians were now saying that, in respect of Christians, "there is no resurrection of the dead" (verses $12 \mathrm{f})$.

27 Ibid, $38 \mathrm{ff}$.

${ }^{28}$ The Origin of 1 Corinthians $91 \mathrm{f}$.

29 Cf. Paul: Libertine or Legalist? $103 \mathrm{ff}$. 
4. Yet at the same time they were being 'baptized on behalf of the dead' (15:29), an activity which suggests that they had at least some hope for the dead, and must have believed in survival after death, though refusing to envisage a bodily resurrection.

5. Paul's discourse in verses $35-50$ about the nature and constitution of the 'resurrection body' suggests they had misunderstood his previous teaching on the subject by thinking of it in a dualistic category.

Many suggestions have been put forward to explain the exact nature of Corinthian belief (or disbelief) in the resurrection, the most widely held theory being that they were influenced by the standard Greek philosophical outlook which accepted immortality of the soul over against resurrection of the body. ${ }^{30:}$ The distinction that Paul makes between the physical and spiritual bodies in verses 35-50 appears at first sight to support this view. But the fundamental assumption that the Corinthians had accepted the resurrection of Jesus can hardly be compatible with this interpretation; nor does this theory provide any adequate explanation of the concept of baptism for the dead, undergoing a material rite in order to produce spiritual blessing. The only explanation of the situation which does justice to all the known facts is the hypothesis of Walter Schmithals, that Paul was here dealing with a Gnostic view of resurrection. ${ }^{31}$

This is the only theory which can offer any sort of convincing explanation of the great confidence with which the Corinthians were opposing Paul's own view of the matter. To the Gnostic, the statement that there is no resurrection would not be, "as it is for Paul an assertion which plunges into the most profound hopelessness, but the triumphant message of one who can renounce all hope because he already possesses by nature his salvation" 32 , a salvation which consists in the fact that he has escaped the flesh and received spiritual liberation. Again, baptism for the dead was known later only in Gnostic circles, and was generally disapproved of by the orthodox church. Yet it was the only sort of baptism that

${ }^{30}$ For a useful summary of the various possibilities, cf. J. H. Wilson, 'The Corinthians who say there is no resurrection of the dead', in $Z N W$ 59 (1968) 90-107.

${ }^{31}$ W. Schmithals, Gnosticism in Corinth, ET Nashville/New York (1971) $155 f$.

${ }^{32}$ Schmithals, op. cit, 158. 
made sense for Gnostics: since they already had their own redemption in the mystical possession of gnosis, they were greatly concerned for the dead, and submitted to the rite of baptism on their behalf in order to secure gnosis for them too. The precise effect of such baptism is uncertain, but in later Coptic Gnosticism there is ample evidence for the performance of a whole series of rites on behalf of the dead. ${ }^{33}$

There is also considerable evidence elsewhere in 1 Corinthians to show that at least some of the Corinthian Christians were moving in a Gnostic direction, and this can only lend support to the view that what Paul is dealing with in 1 Corinthians 15 is a Gnostic type of realised eschatology. ${ }^{34}$ In my view, all the available evidence points in this direction, and does not support the argument of Buck and others, that Paul is fiere dealing with questions about the immediate apocalyptic expectations of Christians in Corinth.

Yet this understanding of the evidence also suggests that, though reaching the correct conclusion, Schmithals has done so by misunderstanding the nature of the evidence at two important points.

He assumes that Paul had himself misunderstood the Corinthians' view, and that the apostle thought they were following the standard approach of Greek philosophy. Schmithals argues that because Paul uses a conventional diatribe formula in verse 35, what follows there says "nothing about circumstances in Corinth, but only reflect Paul's view about those circumstances", a view which Schmithals thinks to have been mistaken. ${ }^{35}$ Yet if that is the case, we can know nothing at all of the Corinthians' beliefs. For since Paul's own statements are our only evidence of the situation, if he was mistaken we can expect to reach no firm conclusions at all. In fact, however, there seems to be no inconsistency between the essential content of the Corinthians' view and the way Paul deals with it. The distinction between flesh and spirit which he makes in verses 35-50 does not necessarily

${ }^{33} \mathrm{Cf}$. Schmithals, op. cit, $156 \mathrm{ff}$.

34 Cf. Paul: Libertine or Legalist? 98ff. Of course, we now know that not all Gnostics subscribed to precisely this type of realised eschatology. Cf. M. L. Peel, 'Gnostic eschatology and the New Testament', in NovT 12 (1970) 141-165. But it is still clear that it was the predominart view even of later Gnosticism, and despite the many criticisms of his position, Schmithals' argument at this point can still be sustained.

${ }^{35}$ Schmithals, op. cit, 156. 
indicate that he thought his opponents were Greek philosophers, for the Gnostics themselves held the same kind of dualistic world-view. In addition, Paul does recognise here that the Corinthians accepted the resurrection of Jesus, and that they were having themselves baptised for the dead and it is hard to see why, given that information, he should himself have drawn any other conclusion than the one that we have drawn, viz. that the Corinthians accepted an after-life, but doubted whether resurrection was directly connected with that.

Schmithals also misses the point both of Paul's reply and of the Corinthians' questions because he fails to recognise that the view, 'there is no resurrection of the dead', is itself based on a misunderstanding of Paul's own teaching. Schmithals asserts rather that the Gnostic view of resurrection had arisen in Corinth as a result of purely external influences: "there ... is no question that it was ... the Gnostic myth imported into Corinth that was the basis of the denial of the resurrection". ${ }^{36}$ No doubt the general intellectual attitude of the day did play its part in determining the form of Corinthian Christianity, but the recognition that the teaching of Paul himself also played its part in the production of a Gnostic belief about resurrection is of the greatest importance, not only for our understanding of the situation in Corinth but also for the proper appreciation of the nature of Paul's theology.

For it is clear that "The idea of a resurrection that has already happened is genuinely Christian ...". ${ }^{37}$ What is more, it is genuinely Pauline, and the unmistakeable implication of that is the observation of James Moffatt, that "these mystical individuals appealed to the teaching of Paul himself. Had he not taught them that Christians are raised to newness of life already, dying inwardly to sin as they were baptised?"38 Given that the Corinthians were holding a Gnostic belief about resurrection, and given that they had derived this, at least in part, from Paul's own teaching, it is difficult not to connect this misunderstanding with his teaching on dying and rising with Christ, which is the only part of Paul's theology that could be misinterpreted in such a way.

${ }^{36}$ Gnosticism in Corinth $156 f$.

${ }^{37}$ C. K. Barrett, A Commentary on the First Epistle to the Corinthians, London (1968) 348.

${ }^{38}$ J. Moffatt, The First Epistle of Paul to the Corinthians, London (1938) 241. 
But that is a part of his teaching which according to Buck and those who follow him was not articulated until a much later stage in Paul's writings. It first appeared, in Buck's view, in Galatians and Romans (both written after 1 Corinthians), and became progressively more important as Paul's thought matured. Thus Buck can summarise Paul's eschatological teaching in the following way: "According to the early letters the believer will be changed, according to the middle letters he is being changed, and according to the last letters he has been changed." ${ }^{39}$ This is the kind of neat scheme that appeals to us all. But unfortunately it founders on the rock of hard fact. For if we take seriously the evidence of 1 Corinthians 15 , the so-called third stage of Buck's reconstruction must have been present in Pauline thought not only before the writing of 1 Corinthians, but also before Paul's initial teaching to the Corinthian church. This means that we can reasonably expect to find some trace of this doctrine in at least one letter that represents a stage in Paul's career earlier than the Corinthian correspondence.

\section{IV}

The most obvious place to look, perhaps, is to the correspondence with the church at Thessalonica, which on any assessment of the evidence is prior to the writing of 1 and 2 Corinthians. Yet in neither of the Thessalonian letters is there any trace of that semi-realised aspect of Paul's eschatology that probably formed the basis of this part of the Corinthian heresy. Only in two passages in 1 Thessalonians $(4: 14,5: 10)$ does Paul use the motif of dying and rising with Christ, though in both the emphasis is on the future expectations of Christians, just as it is in 1 Corinthians $15 .^{40}$ There is no trace of that mystical connexion with the death and resurrection of Christ that is so prominent in Romans and Galatians, and though Paul uses a similar form of words he is referring to a different reality.

Yet alongside this, we are faced with the fact that at least one element in the situation at Thessalonica displays a marked similarity to the situation that was found in Corinth. For 2 2 Thessalonians 2:2 refers again to a group of people who believed 'that the day of the Lord has come' - a statement which

${ }^{39}$ St. Paul $14 \mathrm{f}$.

40 R. C. Tannehill, Dying and Rising with Christ, Berlin (1967) $132 \mathrm{ff}$. 
can only indicate some kind of realised eschatology of the same type as in Corinth. Following up this clue, Schmithals has traced a number of other allegedly anti-Gnostic arguments in the rest of 1 and 2 Thessalonians, all of which can be paralleled elsewhere in Paul's writings. Thus, Paul defends himself against the "typical Gnostic charges" of not being a pneumatic $(1: 5,9 ; 2: 1-2)$; he deals with the ethical problems of the Thessalonians on a similar basis $(4: 3-8)$, and in the light of 2 Thessalonians 2:2, 1 Thessalonians 4:13-5:11 can also be seen to be dealing with a Gnostic type of eschatology. ${ }^{41}$

It is highly unlikely that the eschatological problems dealt with in 1 Thessalonians stem from this source. But at the same time, the conclusion seems inescapable that what we have to deal with in 2 Thessalonians $2: 2$ is something quite different, and more akin to the Gnostic eschatology of the Corinthians and of the later heretics spoken of in 2 Timothy $2: 18$. In reply to this suggestion, Paul goes to some lengths in 2 Thessalonians to make it plain that the day of the Lord', which of course included final resurrection, was something that would happen in an open way, and was connected with specific events in history, and not just with the existential condition of individual Christians. The character of Paul's reply suggests that he was dealing with two problems at once, and this probably explains why it is not clear what he thought of the suggestion that the 'day of the Lord' may indeed be here already. On the one hand, he is replying to those of a Gnostic bent, who had apparently misunderstood some message from him to mean that their own present experience was the only eschatological reality of the Christian faith - and to them he emphasises that his eschatology is in essence little different from that of his Jewish predecessors, and is to be grounded in history. On the other hand, other Christians, who realised the historically-based nature of Paul's expectation, having heard the claims of some that the resurrection had occurred, were thrown into an even deeper confusion than they had been in before. Their prior concern, as reflected in 1 Thessalonians 4:15, had been that their departed friends would miss the blessings of the parousia. "Now they were thinking, 'We have all missed them.' For if the day of

${ }^{41}$ W. Schmithals, Paul and the Gnostics, ET Nashville/New York (1972) 123-218. 
the Lord had really come, it had come - and gone. For where was the Lord and why were they not with him? They must have missed it all." ${ }^{2}$ In answer to these people, Paul makes it plain not only that the events of the end would be externally attestable, but also that they were to occur in a specified order.

According to K. Lake, following Harnack, the explanation for all this is to be found in the assumption that 1 and 2 Thessalonians were written to different groups within the church, if not to different churches in Thessalonica. ${ }^{43}$

1 Thessalonians was written to Gentile Christians, and 2 Thessalonians to Jewish believers, and on this basis the distinctions in eschatological teaching between them stem from the fact that Gentiles and Jews had different presuppositions about such matters. What is said on the parousia in 1 Thessalonians would, according to Lake, be "defective from the Jewish point of view in that it omitted a statement of the necessary development of evil in the days immediately preceding the coming of Messiah." 44 Paul therefore wrote 2 Thessalonians, to repeat much of his earlier teaching, but omitting anything offensive to Jews, and adding the new section about the antichrist.

This kind of theory cannot be accepted, not least because it ignores the explicit evidence of the two epistles that they were written to the same set of people (cf. the addresses and 2 Thess. 2:15). But it also suffers from more serious defects. It is easy to assert that the realised eschatological expectations implied in 2 Thessalonians $2: 2$ are based on a misunderstanding of the teaching of 1 Thessalonians. But it is not so easy to prove it. Indeed it is hard to find anything anywhere in 1 Thessalonians that could even remotely suggest a realised eschatology of any kind. Quite the opposite is the case, for the same basic approach to the matter is preserved in each epistle - indeed the similarity of the two is one of the reasons most often pressed for seeing a problem here at all! Yet we do have the explicit statement in 2 Thessalonians $2: 2$ that the view of some of them that 'the day of the Lord' has already come was grounded on an alleged communication from Paul himself. It seems unlikely that an actual forgery of an apostolic letter is in view here, otherwise Paul would have

${ }^{42}$ R. A. Ward, Commentary on 1 \& 2 Thessalonians, Waco (1973) 154f.

43 K. Lake, The Earlier Epistles of St. Paul, London (1911) $61 \mathrm{ff}$.

44 Op. cit, 90. 
refuted its implications in a more forthright fashion than he does.

There are, then, two facts with which we need to reckon in the understanding of Paul's dealings with the Thessalonians:

$i$ There was a group in the church who held to a Gnostic type of realised eschatology.

ii They claimed to have the authority of Paul himself for this view.

In both these respects, the situation in Thessalonica proves to be closely parallel to that in Corinth. We have already seen that the part of Paul's eschatology that could most easily be misunderstood in a Gnostic way was his emphasis on a mystical sharing in the death and resurrection of Christ, such as he expounds in Galatians and Romans. So we are not surprised to discover that the problem mentioned in 2 Thessalonians 2:2 was not based on a misunderstanding of 1 Thessalonians, for there is no explicit mention of the mystical death and resurrection of Christians in that letter. ${ }^{45}$

Where, then, could the Thessalonians have gained the impression that Paul's own teachings supported a Gnostic type of realised eschatology? There seems to be only one possible answer, and that is in the assumption that Galatians must have been written before the Thessalonian correspondence, and that this may be the letter to which Paul's opponents in Thessalonica were appealing for support.

It is therefore apparent that the evidence of the variations in Pauline eschatology, which according to Buck prove that there was a straight line of development from primitive apocalyptic to 'realised' expectations, in fact prove no such thing. Rather can we see a straight line of development from the extreme way Paul opposed a Judaizing Christianity in Galatians, through a Gnostic type of misunderstanding of his message first in Thessalonica, and then more extensively in Corinth, leading to the articulation of a 'neutral' theology, susceptible of misinterpretation by neither Judaizers nor Gnostics, which makes its first appearance in Romans, with 2 Corinthians 1-9 as a halfway stage in the synthesis. ${ }^{46}$

45 As a by-product of this view that two distinct types of misunderstanding are envisaged here, not directly connected with each other, we are also enabled to postulate a realistic Sitz im Leben for the problematical second letter.

${ }^{46}$ Paul: Libertine or Legalist? $132 \mathrm{ff}$. 
Far from requiring the abandonment or modification of previous conclusions, therefore, the evidence of diversity in the eschatological viewpoint of the Pauline epistles strengthens the case already made. What is more, the very diversity which we can trace here between realised and apocalyptic eschatology in the letters we have dealt with, is itself strong enough evidence to support the contention that:Paul's thought did not in fact develop in any formal way, for both extremities of the eschatological spectrum are held clearly in view from the outset. Which one is in sharp focus at any given moment is determined by external factors, especially the character of the opponents whom Paul was facing. In response to the Judaizers of Galatia, for whom religion was a matter of intellectual and legally defineable propositions, Paul emphasises that to know Christ is a matter of personal experience. On the other hand, the Gnostics in Corinth had no need of such instruction, for they already believed that everything was to be understood and encountered on the existential level - and to them Paul emphasises that the Christian message can never be separated from the action of God in history.

To emphasise these different aspects of his theology was nothing more than commonsense to Paul, in opposing those whom he thought to be wrong. But when we come to Romans, we find that Paul unites both parts of his thought, so that we have at one and the same time an emphasis on the Christian's sharing in the death and resurrection of Christ and, though there is no explicit mention of the parousia of Christ, a corresponding emphasis on Paul's conviction that God was in control of the course of history, and that he would yet intervene eschatologically in a tangible way.

We can, however, hardly deny that for Paul his present relationship to Christ was of supreme importance, and was the framework within which the whole of his theology was enclosed. This again is quite in character with what we know of Paul, for he was never the man to be merely a religious theorist. Perhaps he was not a theologian at all. He was certainly first and foremost a pragmatist, and what mattered to him most of all was his own encounter with the living Christ, an encounter in which he had been "confronted with a Saviour who forgave him not in the diluted sense of an 
amnesty but in such a way that what had been his death became his resurrection." 47 We see Paul in proper perspective only when we view him in the light of this: as a man crucified with Christ, and enjoying the new power of Christ's resurrection life within him, whose one burning ambition was to communicate to everyone else he met, by whatever means he could use, this Christ and this resurrection.

${ }^{47}$ A. Schlatter, The Church in the New Testament Period, ET London (1955) 100. 